\title{
An Empirical Analysis of the Development Level of Rural Social Security in Sichuan Province
}

\author{
Ziwei Zheng ${ }^{1}$, Shubin Jin ${ }^{2, *}$ \\ ${ }^{1}$ School of Management, Chengdu University of Information Engineering, Chengdu, 610100, China; \\ ${ }^{2}$ School of Management, Chengdu University of Information Engineering, Chengdu, 610100, China; \\ *Corresponding author.Email: jsbin@cuit.edu.cn
}

\begin{abstract}
Driven by the poverty alleviation and rural revitalization strategy, the development of rural social security in Sichuan Province has been improved in recent years. The purpose of this study is to find out how the level of rural social security development in Sichuan Province ranks nationally, and the research method was the application of principal component analysis for empirical analysis. The conclusion is that Sichuan Province ranks 24th among the 31 provinces, and does not adapt to the overall economic development. The main reasons for this result according to the analysis of relevant materials are the lack of financial investment in rural social security and the gap between rural social security and urban social security. Thus, some reasonable suggestions are put forward.
\end{abstract}

Keywords: Sichuan Province, Rural social security, Empirical analysis, Principal component analysis.

\section{INTRODUCTION}

Sichuan Province is a large developing province in southwest China with a large rural population. Driven by the poverty alleviation and rural revitalization strategy, the development of rural social security in Sichuan Province has been improved in recent years. To understand the development level of rural social security in Sichuan Province more objectively, this paper presents an empirical analysis of the developmentlevel of rural social security in Sichuan Province based on the research of the following scholars on the "development level of rural social security", and further arouses the government's attention to some problems in the continuous development of rural social security.

Developed countries basically have no research on rural social security. At present, foreign scholars focus on evaluating the leve1 of social security from the perspective of influencing factors, such as Peng Yu (2010) analyzed the data of time series from 1992 to 2006 in the United States and concluded that population aging is an important influencing factor for the 1evel of socia1s security ${ }^{[1]}$. However, domestic scholars have conducted relatively more studies on the level of rural social security based on China's national conditions. Bian Yan (2007) explored the selection of indicators in three subsystems of rural social security, namely, rural pension insurance, rural medical cooperation, and minimum living security, in terms of security level, coverage, and output benefits ${ }^{[2]}$; Zhao Guang (2013) constructed 12 indicators of rural social security level from three dimensions of range, security degree and sustainability ${ }^{[3]}$, which were evaluated by entropy weight method and cluster analysis; He Shuping (2009) and Xin Liqiu (2013) used a set of evaluation model according to the theory of "appropriate level of social security" to calculate the development level of rural social security in Heilongjiang Province ${ }^{[4-5]}$; Wang Qi (2016) and Zhang Zhidan (2018) constructed more than ten indicators from the four aspects of rural social insurance, social assistance, social welfare and social preferential care, using the principal component model and AHP hierarchical analysis for empirical analysis respectively ${ }^{[6-7]}$

Based on the above research, the principal component analysis model of SPSS data analysis software is used for analysis in this paper. And the principle of principal component analysis is to transform multiple indicators into a few comprehensive indicators by dimension reduction, and retain as much information as possible in the case of eliminating covariance ${ }^{[8]}$. 


\section{EMPIRICAL ANALYSIS PROCESS}

\subsection{Construction of Evaluation Indicators and Data Sources}

The evaluation indicators of rural social security level should be quantified, publicly available for a query as far as possible, so this model selected indicators and public data common to all provinces in China and constructed the following hierarchy of evaluation indicators of rural social security level in Table 1.

Table 1. Evaluation indicators of rural social security level in Sichuan Province

\begin{tabular}{|c|c|c|}
\hline $\begin{array}{l}\text { tier } 1 \\
\text { indicator }\end{array}$ & $\begin{array}{l}\text { Secondary } \\
\text { indicators }\end{array}$ & Tertiary indicators \\
\hline \multirow{16}{*}{$\begin{array}{c}\text { Rural } \\
\text { social } \\
\text { security } \\
\text { level }\end{array}$} & \multirow{4}{*}{$\begin{array}{c}\text { Social } \\
\text { insurance }\end{array}$} & $\mathrm{X}_{1}$ : Participation Rate of Medical Insurance in Urban and Rural Areas (\%) \\
\hline & & $\mathrm{X}_{2}$ : Per capita income of urban and rural medical insurance fund (yuan) \\
\hline & & $\mathrm{X}_{3}$ : Receipt rate of urban and rural pension insurance $(\%)$ \\
\hline & & $\mathrm{X}_{4}$ : Per Capita Pension Insurance for Urban and Rural Residents (Yuan) \\
\hline & \multirow{5}{*}{$\begin{array}{c}\text { Social } \\
\text { assistance }\end{array}$} & $\mathrm{X}_{5}$ :Coverage rate of minimum living security for rural residents \\
\hline & & $\mathrm{X}_{6}$ : Per capita minimum living security for rural residents ( yuan ) \\
\hline & & $\mathrm{X}_{7}$ : Coverage rate of support for people in undue difficulty $(\%)$ \\
\hline & & $\mathrm{X}_{8}$ : Rate of centralized care for people in undue difficulty $(\%)$ \\
\hline & & $\mathrm{X}_{9}$ : Per capita amount of medical aid ( yuan ) \\
\hline & \multirow{4}{*}{$\begin{array}{l}\text { Social } \\
\text { welfare }\end{array}$} & $\mathrm{X}_{10}$ : Number of beds in townships health centers per 1,000 rural population (one) \\
\hline & & $\begin{array}{l}\mathrm{X}_{11} \text { : Number of Health staff in townships health centers per } 1,000 \text { rural population } \\
\text { (pcs) }\end{array}$ \\
\hline & & $\mathrm{X} 1_{2}:$ Number of rural community service agencies (a) \\
\hline & & $\mathrm{X}_{13}$ : Number of elderly beds per 1,000 elderly population (pcs) \\
\hline & \multirow{3}{*}{$\begin{array}{l}\text { Social } \\
\text { Preferential } \\
\text { care }\end{array}$} & $\mathrm{X}_{14}$ : Per capita living allowance for merit recipients (yuan) \\
\hline & & $\mathrm{X}_{15}:$ Per capita medical benefits for merit recipients (yuan) \\
\hline & & $\mathrm{X}_{16}$ : Replacement rate of per capita subsistence allowance for merit recipients $(\%)$ \\
\hline
\end{tabular}

The data sources for the 16 indicators are the National Bureau of Statistics "China Statistical Yearbook 2020", downloadable data from the website of the Ministry of Finance of China, and data compiled from provincial government documents.

\subsection{Process of Empirical Analysis}

\subsubsection{KMO and Bartle Spherical Tests}

The value of KMO is considered suitable for factor analysis if it is greater than 0.5 , and the value of Bartle spherical test, named the Sig value, passes the test when it is less than 0.01 . The test result of the data in this paper is that KMO value was 0.708 and Bartle's sig value was 0.000 , which indicates that it has passed the test.

\subsubsection{Total Variance Interpretation and Factor Load Rotation}

As shown in Table 2, the eigenvalue values of the first four principal components are all greater than 1, and the cumulative total variance reaches $80.1 \%$, indicating that the extracted principal components can reflect $80 \%$ of the information of the original data, so the first four principal components are used as a measure of the level of rural social security. 
Table 2. Interpretation of Cumulative Total Variance

\begin{tabular}{|c|l|l|l|l|l|l|l|l|l|}
\hline & \multicolumn{3}{|c|}{ Initial eigenvalue } & \multicolumn{3}{c|}{$\begin{array}{c}\text { Extract the sum of the } \\
\text { squares of the load }\end{array}$} & \multicolumn{3}{c|}{$\begin{array}{c}\text { Sum of squares } \\
\text { of rotating loads }\end{array}$} \\
\hline composition & total & $\begin{array}{c}\text { Variance } \\
\%\end{array}$ & $\begin{array}{c}\text { Cumulative } \\
\%\end{array}$ & total & $\begin{array}{c}\text { Variance } \\
\%\end{array}$ & $\begin{array}{c}\text { Cumulative } \\
\%\end{array}$ & total & $\begin{array}{c}\text { Variance } \\
\%\end{array}$ & $\begin{array}{c}\text { Cumulative } \\
\%\end{array}$ \\
\hline 1 & 6.445 & 40.282 & 40.282 & 6.445 & 40.282 & 40.282 & 6.197 & 38.729 & 38.729 \\
\hline 2 & 4.099 & 25.621 & 65.904 & 4.099 & 25.621 & 65.904 & 3.729 & 23.305 & 62.034 \\
\hline 3 & 1.245 & 7.783 & 73.687 & 1.245 & 7.783 & 73.687 & 1.517 & 9.480 & 71.514 \\
\hline 4 & 1.027 & 6.421 & 80.108 & 1.027 & 6.421 & 80.108 & 1.375 & 8.594 & 80.108 \\
\hline 5 & 0.854 & 5.340 & 85.448 & & & & & & \\
\hline$\ldots .$. & $\ldots \ldots$ & $\ldots \ldots$ & $\ldots \ldots$ & & & & & & \\
\hline
\end{tabular}

Next, the factors were rotated using the maximum variance method to obtain the rotated component matrix, as shown in Table 3. Most of the factors in the first principal component have higher load, which is named "foundation support factor" and replaced by "F1"; In the second principal component, the Per capita amount of medical assistance, Per capita living allowance and Replacement rate of per capita subsistence allowance for merit recipients are higher, which is called "direct security expenditure factor" and replaced by "f2"; In the third principal component, the Coverage rate of minimum living security for rural residents, Participation Rate of Medical Insurance in Urban and Rural Areas and the Number of rural community service agencies are higher, which is named "security coverage factor" and replaced by "f3"; In the fourth principal component, Number of elderly beds per 1,000 elderly population and Rate of centralized care for people in extreme hardship are higher, named "sustainable security factor" and replaced by "f4".

\subsubsection{Empirical Result}

After the score coefficient matrix is obtained by factor rotation, each principal component is combined linearly.

$$
\mathrm{fl}=-0.147 \mathrm{X}_{1}+0.135 \mathrm{X}_{2}+0.105 \mathrm{X}_{3}+0.169 \mathrm{X}_{4}-0.071 \mathrm{X}_{5}
$$
$+0.136 \mathrm{X}_{6}+0.014 \mathrm{X}_{7}-0.128 \mathrm{X}_{8}-0.030 \mathrm{X}_{9}-0.156 \mathrm{X}_{10}+1 \mathrm{X}_{11}-0$ $116 \mathrm{X}_{12}-0.073 \mathrm{X}_{13}+0.012 \mathrm{X}_{14}-0.037 \mathrm{X}_{15}+0.042 \mathrm{X}_{16}$

$$
\mathrm{f} 2=-0.029 \mathrm{X}_{1}-0.018 \mathrm{X}_{2}-0.044 \mathrm{X}_{3}-0.005 \mathrm{X}_{4}-0.133 \mathrm{X}_{5}+0
$$

$.001 \mathrm{X}_{6}+0.142 \mathrm{X}_{7}+0.016 \mathrm{X}_{8}+0.365 \mathrm{X}_{9}+0.030 \mathrm{X}_{10}+0.046 \mathrm{X}_{11}$ $+0.056 \mathrm{X}_{12}-0.047 \mathrm{X}_{13}+0.256 \mathrm{X}_{14}+0.181 \mathrm{X}_{15}+0.253 \mathrm{X}_{16}$

$$
\mathrm{f} 3=-0.075 \mathrm{X}_{1}-0.057 \mathrm{X}_{2}+0.166 \mathrm{X}_{3}-0.041 \mathrm{X}_{4}-0.598 \mathrm{X}_{5}+
$$
$0.091 \mathrm{X}_{6}-0.022 \mathrm{X}_{7}+0.319 \mathrm{X}_{8}+0.376 \mathrm{X}_{9}+0.125 \mathrm{X}_{10}+0.022 \mathrm{X}_{1}$ ${ }_{1}+0.417 \mathrm{X}_{12}-0.046 \mathrm{X}_{13}+0.023 \mathrm{X}_{14}-0.115 \mathrm{X}_{15}+0.092 \mathrm{X}_{16}$

$\mathrm{f} 4=0.050 \mathrm{X}_{1}+0.099 \mathrm{X}_{2}+0.024 \mathrm{X}_{3}-0.235 \mathrm{X}_{4}+0.178 \mathrm{X}_{5}+$ $0.032 \mathrm{X}_{6}+0.422 \mathrm{X}_{7}-0.044 \mathrm{X}_{8}+0.038 \mathrm{X}_{9}+0.122 \mathrm{X}_{10}+0.197 \mathrm{X}_{1}$ ${ }_{1}+0.179 \mathrm{X}_{12}+0.648 \mathrm{X}_{13}-0.014 \mathrm{X}_{14}-0.023 \mathrm{X}_{15}-0.059 \mathrm{X}_{16}$

The following is the formula for calculating the composite score of rural social security level.

$$
F=(38.729 f 1+23.305 f 2+9.480 f 3+8.594 f 4) / 80.108
$$

The component coefficients of the 31 provinces in Table4 below were then brought into the above formula, and the SPSS calculations yielded the ranking of the overall score of the level of rural social security development in each province in 2019. As shown in Table 4, Sichuan Province ranks 24th in China. From the score of each principal component, the score of "basic security factor" of Sichuan Province is -0.96691 , which is the last among the 31 provinces in China; "Direct security expenditure factor" is also negative, which harms the overall level of rural social security. Therefore, Sichuan Province should strengthen the basic financial expenditure. The scores of the third and fourth principal components rank seventh, which indicates that the rural social security coverage in Sichuan Province is wide and the sustainability of the old-age security work is good. 
Table 3. Rotation Component Matrix

\begin{tabular}{|c|c|c|c|c|}
\hline \multicolumn{7}{|c|}{ Rotating component matrix } \\
\hline & Component 1 & Component 2 & Component 3 & Component 4 \\
\hline $\mathrm{X} 1$ & -.892 & .015 & -.134 & -.056 \\
\hline $\mathrm{X} 2$ & .898 & -.062 & .005 & .238 \\
\hline $\mathrm{X} 3$ & .750 & -.388 & .348 & .152 \\
\hline $\mathrm{X} 4$ & .841 & .018 & -.026 & -.194 \\
\hline $\mathrm{X} 5$ & -.500 & .165 & -.759 & .114 \\
\hline $\mathrm{X} 6$ & .904 & -.146 & .198 & .167 \\
\hline $\mathrm{X} 7$ & .372 & .473 & -.117 & .563 \\
\hline $\mathrm{X} 8$ & -.702 & -.248 & .406 & -.114 \\
\hline $\mathrm{X} 9$ & -.115 & .942 & .155 & .025 \\
\hline $\mathrm{X} 10$ & -.829 & -.002 & .112 & .058 \\
\hline $\mathrm{X} 11$ & .769 & .081 & .055 & .346 \\
\hline $\mathrm{X} 12$ & -.423 & -.254 & .551 & .211 \\
\hline $\mathrm{X} 13$ & .060 & -.217 & .058 & .833 \\
\hline $\mathrm{X} 14$ & -.011 & .927 & -.249 & -.052 \\
\hline $\mathrm{X} 15$ & .167 & .838 & -.136 & -.079 \\
\hline $\mathrm{X} 16$ & -.354 & .820 & -.396 & -.113 \\
\hline
\end{tabular}

Thus, the current rural social security in Sichuan Province is characterized by low level, coverage widely and strong sustainability. Through the analysis of some relevant materials, this paper discussed the following main reasons for the low level of rural social security in Sichuan Province.

\section{REASONS DISCUSSED}

\subsection{Insufficient Financial Support for Rural Social Security}

The allocation of rural social security financial resources plays a decisive role allocating rural social security resources ${ }^{[9]}$. Generally, the higher a region's GDP is, the higher its social security level is. Sichuan's GDP and public financial revenue ranked 6th and 7th in the country in 2019, which means that the financial expenditure on rural social security is relatively more powerful. However, in contrast, Tibet's GDP in 2019 is only $3.6 \%$ of Sichuan's GDP, but the per capita expenditure on rural social insurance is 3166.94 yuan, much higher than 2548.10 yuan in Sichuan Province. From the perspective of farmers' income and local prices, Sichuan's rural per capita disposable income ranked 21st in China in 2019; The CPI of Sichuan Province was 103.2, which was 1.5 higher than that of 2018 , It was the province with the largest CPI increase in China, reflecting the low income of farmers and high local prices in Sichuan Province. Therefore, it shows that Sichuan Province has certain financial strength, but it does not allocate financial resources to rural social security in time according to the situation of low income of farmers and high local prices. 
Table 4. Comprehensive ranking of rural social security level by province nationwide

\begin{tabular}{|c|c|c|c|c|c|c|}
\hline region & FAC1_1 & FAC2_1 & FAC3_1 & FAC4_1 & $\begin{array}{c}\text { Comprehensive } \\
\text { score }\end{array}$ & Ranking \\
\hline Shanghai & 3.57883 & -.18913 & .04028 & -.33054 & 1.64 & 1 \\
\hline Beijing & 2.53996 & .71520 & .73134 & .68274 & 1.60 & 2 \\
\hline Tibet & -.44557 & 4.62731 & 1.27580 & -.12545 & 1.27 & 3 \\
\hline Zhejiang & .98164 & -.48473 & .06109 & 3.56158 & .72 & 4 \\
\hline Tianjin & 1.82571 & -.44048 & .17139 & -1.35224 & .63 & 5 \\
\hline Xinjiang & -.09063 & 1.40815 & -2.02855 & .41721 & .17 & 6 \\
\hline Qinghai & -.12029 & 1.08765 & -1.13661 & -.27922 & .09 & 7 \\
\hline Jiangsu & .09119 & -.64832 & .88573 & 1.12487 & .08 & 8 \\
\hline Shandong & -.51626 & -.22236 & 1.89333 & .63212 & -.02 & 9 \\
\hline Shaanxi & -.34343 & .28141 & .33122 & .15125 & -.03 & 10 \\
\hline Jilin & -.02820 & -.03096 & .06365 & -.40242 & -.06 & 11 \\
\hline Heilongjiang & .05425 & -.09936 & -.03303 & -.57652 & -.07 & 12 \\
\hline Ningxia & .09265 & .47565 & -2.29691 & .06372 & -.08 & 13 \\
\hline $\begin{array}{c}\text { Inner } \\
\text { Mongolia }\end{array}$ & -.41414 & .12823 & -1.10875 & 1.71264 & -.11 & 14 \\
\hline Fujian & .43215 & -.83182 & .02347 & -.81901 & -.12 & 15 \\
\hline Guangdong & .12528 & -.75311 & .57404 & -.38697 & -.13 & 16 \\
\hline Liaoning & -.02130 & -.31068 & .59805 & -.98667 & -.14 & 17 \\
\hline Hainan & .24059 & .01083 & -.34925 & -2.17884 & -.16 & 18 \\
\hline Shanxi & -.40581 & .16366 & .50630 & -.64519 & -.16 & 19 \\
\hline Hubei & -.60209 & -.36969 & .59874 & .71096 & -.25 & 20 \\
\hline Hebei & -.51592 & -.54425 & .98759 & .08013 & -.28 & 21 \\
\hline Jiangxi & -.34312 & -.32996 & -.58317 & .24062 & -.31 & 22 \\
\hline Hunan & -.71318 & -.20328 & 1.03787 & -.36601 & -.32 & 23 \\
\hline Sichuan & -.96691 & -.14277 & .84613 & .51860 & -.35 & 24 \\
\hline Henan & -.84153 & -.35299 & 1.01489 & -.49807 & -.44 & 25 \\
\hline Anhui & -.70932 & -.62968 & .25376 & .14745 & -.48 & 26 \\
\hline Gansu & -.59947 & -.29408 & -.89160 & -.06873 & -.49 & 27 \\
\hline Guizhou & -.51522 & -.43409 & -1.66990 & .50627 & -.52 & 28 \\
\hline Yunnan & -.27628 & -.44037 & -1.35857 & -.90188 & -.52 & 29 \\
\hline Chongqing & -.71045 & -.49925 & .13715 & -.47361 & -.52 & 30 \\
\hline Guangxi & -.78314 & -.64673 & -.57547 & -.15880 & -.65 & 31 \\
\hline
\end{tabular}




\subsection{There are Gaps in Social Security between Urban and Rural Areas}

At present, a large number of rural labor force flow to urban employment, one of the reasons is that the social security system of urban population is more comprehensive, covers a wider range, and has a higher level of security ${ }^{[10]}$. The rural social insurance in Sichuan Province only pays attention to the basic pension and medical problems of farmers, without the protection of "five insurances and one fund" in cities, and many farmers are only willing to participate in the low-grade pension insurance standard. There are local differences in the compensation mechanism of urban and rural medical insurance and the process of reimbursement in other places is difficult, leading to some sick migrant workers can only return home for treatment. The monthly minimum living standard for rural areas in Sichuan Province is always about 180 yuan lower than that in cities. About rural welfare, the elderly in rural areas cannot rely on land to solve the problem of pension completely, but also lack of spiritual care, which is due to the weakening of land security function and the fact that family youth are working outside all the year round, and the fact that rural community culture and entertainment activities are less than those in cities. Whether from the perspective of "quality" or "quantity", there are some gaps between urban and rural social security in Sichuan Province.

\section{CONCLUSION AND SUGGESTIONS}

Our government's continuous efforts to strengthen rural social security have caused many scholars to study rural social security. Taking Sichuan province as an example, this paper used the principal component analysis model to develop an empirical analysis based on the research results of existing scholars, and obtained that the level of rural social security development in Sichuan province in 2019 was ranked 24th in the country, which is relatively low. In fact, the total economic output of Sichuan Province ranked high in the national ranks, but the empirical results proved that the rural social security of Sichuan Province did not adapt to its economic development. The main reasons for the low ranking according to the analysis of relevant materials are insufficient financial expenditure and the gap between urban and rural social security. Therefore, this paper suggests that:

In today's high-quality economic development, the government should timely compensate the fiscal revenue to the position of rural social governance, strengthen the financial investment in rural social security and narrow the gap between urban and rural social security. The premise of enhancing financial investment is to pour in localized agricultural policies for the less developed regions to develop local economy, improve farmers' income and promote farmers' social security consumption. Narrowing the gap between urban and rural social security requires unified planning from various aspects such as national systems, policies and financing channels, so that farmers can truly enjoy fair social security treatment.

\section{AUTHORS' CONTRIBUTIONS}

The first author of this paper proposed the research topic, data collection, statistical analysis, and writing of the paper; the second author participated in the design of the paper framework, selection of data indicators, guidance of the paper writing process, and research funding support.

\section{ACKNOWLEDGMENTS}

I am grateful for the help and guidance of my supervisor, and the review and advice of fellow experts in this paper. I also thank the related scholars for reprinting and citing the literature, which gave me knowledge and inspiration to write.

\section{REFERENCES}

[1] Peng Yu I. Social security claiming of the elderly in the United States [J]. 2010.

[2] Bian Yan. Exploration of key factors and related indicators of rural social security level [J]. Journal of East China. 2007, (02), pp.108-112

[3] Zhao Guang. The construction and evaluation of the index system of rural social security development level_Taking Jiangsu Province as an example [J].Journal of Jiangxi University of Finance and Economics. 2013, (05), pp.71-78

[4] He, Shu-Ping, Zuo, Li-Wei. Analysis of social security level in rural Heilongjiang Province [J]. Journal of Harbin University of Commerce (Social Science Edition) 2009, (06), pp.18-20

[5] XIN Liqiu, ZHU Xiao, XIE Yu. Analysis of the development level of social security in rural Heilongjiang Province [J]. Fiscal Research. 2013, (08), pp.55-58

[6] Wang Qi. Research on the evaluation and improvement of social security level in rural Heilongjiang Province [D]. Northeast Agricultural University.2016

[7] Zhang Zhidan. Research on the evaluation and improvement of social security level in rural Hunan Province [D]. Hunan University. 2018

[8] Jiao Xingrui, Kong Yang, Chen Min, Comprehensive assessment of agricultural insurance based on principal component analysis 
method - taking Heilongjiang province as an example [J]. Gansu Finance.2019,(08), pp.38-41

[9] Ye Jinguo, Qiu Xiaojie. Study on the allocation of financial resources for social security in rural China and countermeasures [J]. Hebei Journal. 2015, 35(04), pp.127-131

[10] Zi Chen Qiong. Analysis on the difference of social security level between urban and rural areas in China and the idea of overall planning [J]. 2019, 8(06), pp.37-40. 